Article

\title{
Evapotranspiration and Surface Energy Fluxes Estimation Using the Landsat-7 Enhanced Thematic Mapper Plus Image over a Semiarid Agrosystem in the North-West of Algeria
}

\author{
Nehal Laounia, Hamimed Abderrahmane, Khaldi Abdelkader, Souidi Zahira, Zaagane Mansour \\ Research on Biological Systems and Geomatics Laboratory, \\ University Mustapha Stambouli of Mascara, Mascara, Algeria.
}

Received: February 2, 2017 - Accepted: July 05, 2017

\begin{abstract}
Monitoring evapotranspiration and surface energy fluxes over a range of spatial and temporal scales is crucial for many agroenvironmental applications. Different remote sensing based energy balance models have been developed, to estimate evapotranspiration at both field and regional scales. In this contribution, METRIC (Mapping EvapoTranspiration at high Resolution with Internalized Calibration), has been applied for the estimation of actual evapotranspiration in the Ghriss plain in Mascara (western Algeria), a semiarid region with heterogeneous surface conditions. Four images acquired during 2001 and 2002 by the Landsat-7 satellite were used. The METRIC model followed an energy balance approach, where evapotranspiration is estimated as the residual term when net radiation, sensible and soil heat fluxes are known. Different moisture indicators derived from the evapotranspiration were then calculated: reference evapotranspiration fraction, Priestley-Taylor parameter and surface resistance to evaporation. The evaluation of evapotranspiration and surface energy fluxes are accurate enough for the spatial variations of evapotranspiration rather satisfactory than sophisticated models without having to introduce an important number of parameters in input with difficult accessibility in routine. In conclusion, the results suggest that METRIC can be considered as an operational approach to predict actual evapotranspiration from agricultural areas having limited amount of ground information.
\end{abstract}

Keywords: evapotranspiration, remote sensing, METRIC, energy balance, Landsat.

\section{Estimativa da Evapotranspiração e Fluxos de Energia de Superfície Usando a Imagem Landsat-7 Enhanced Thematic Mapper Plus em um Agrosistema Aemi-árido no Noroeste da Argélia}

\begin{abstract}
Resumo
O monitoramento dos fluxos de energia e da evapotranspiração em diferentes escalas espaciais e temporais é crucial para muitas aplicações agroambientais. Diferentes modelos baseados no sensoriamento remoto têm sido desenvolvidos para estimativa da evapotranspiração tanto em escala local como em largas escalas. Neste contexto, o METRIC (Mapping EvapoTranspiration at high Resolution with Internalized Calibration) tem sido aplicado para a estimative da evapotranspiração em "Ghriss plain” em Mascara, uma região semiárida no noroeste da Argélia com condições e superfícies heterogêneas. Quatro imagens adquiridas durante 2001 a 2002 com o sensor Landsat-7 ETM+ foram usadas. O modelo METRIC computa o balanço de energia onde a evapotranspiração é estimada como resíduo quando o saldo de radiação e os fluxos de calor sensível e no solo são conhecidos. Diferentes indicadores de umidade derivados da evapotranspiração foram então calculados: a fração da evapotranspiração de referência, o parâmetro Priestley-Taylor e a resistência da superfície à evapotranspiração. As avaliações da evapotranspiração e dos fluxos de energia foram suficientemente precisas para detecção das variações espaciais da evapotranspiração, sendo mais satisfatórias que aquelas provenientes de modelos sofisticados sem a necessidade de introdução de vários parâmetros de difícil obtenção rotineiramente. Concluiu-se que, pelos resultados da aplicação do METRIC, o modelo pode ser considerado operacional para predição da evapotranspiração atual em áreas agrícolas com informações de campo limitadas.
\end{abstract}

Palavras-chaves: evapotranspiração, sensoriamento remote, METRIC, balanço de energia, Landsat.

Corresponding author: Nehal Laounia, laounia2001@yahoo.fr / 1.nehal@univ-mascara.dz. 


\section{Introduction}

Evapotranspiration is one of the fundamental processes controlling the equilibrium of our planet. It constitutes the link between the hydrological and energetic equilibrium at the soil-vegetation-atmosphere interface and its knowledge is crucial for climatic and agrometeorological studies (Khaldi et al., 2011). Nearly two-thirds of precipitation over land is returned back to the atmosphere by the evapotranspiration (Jato et al., 2016). In arid and semiarid regions, water resources are limited and hereby the available groundwater for irrigation and other water uses are severely constrained. Consequently, evapotranspiration constitutes one of major phenomena in the hydrological budget.

Remote sensing data with the increasing imagery resolution is an excellent tool for evapotranspiration monitoring as it provides information related to mass and energy transfers and particularly to evapotranspiration fluxes. Remote sensing technology can provide land surface parameters such as albedo, vegetation indices and surface temperature, which are indispensable to remote sensing-based energy balance models for scaling up evapotranspiration and surface energy fluxes to larger spatial and longer temporal scales. It is recognized as the only way to retrieve evapotranspiration at several temporal and spatial scales (Zhang et al., 2016; Liou et al., 2014). To this end, there has been a major effort over the past several years to develop remote sensing-based methods that provide spatially distributed surface fluxes maps using airborne and satellite data (Khaldi et al., 2011). Basically, these methods can be classified into three main categories:

- Those using simple empirical relationships relating daily evapotranspiration to an instantaneous surface temperature measurement (Trezza, 2006); - Those using deterministic relationships based on more complex models such as Soil-Vegetation-Atmosphere Transfer models (SVAT) (Olioso et al., 1999; Galleguillos et al., 2017; Hartanto et al., 2017). They are mainly used for estimating evapotranspiration, surface energy exchanges and water balance. Most of the transfer mechanisms (radiative, turbulent, and water transfers) and some physiological processes (photosynthesis, stomatal regulation) are described; - Those basing on the estimation of the evapotranspiration as the residual term of the energy balance equation. They can be divided into two categories: 1) Single-source models, such as SEBAL (Surface Energy Balance Algorithm for Land) (Bastiaanssen et al., 1998; Teixeira et al., 2009), METRIC (Mapping Evapotranspiration with Internalized Calibration) (Allen et al., 2007; Trezza et al., 2013; Hamimed et al., 2014), S-SEBI (Simplified Surface Energy Balance Index) (Roerink et al., 2000), SEBS (Surface Energy Balance System) (Su, 2002) and TIM model (the Trapezoid Interpolation Model) (Sun and Kafatos, 2007; Stisen et al., 2008), that do not distinguish between soil evaporation and transpiration, but treat the land surface as one homogeneous surface. Their simplicity and yet physically sound basis has made the single-source models widely used; 2) Dual-source models, such as TSEB (Two Source Energy Balance) (French et al., 2015; Boulet et al., 2015; Xin et al., 2010), that discriminate the soil and vegetation component, aiming at a more physical description of heterogeneous surfaces when dealing with radiative and aerodynamic properties. However, they have limitations related to the difficulty of obtaining temperatures for the soil and vegetation.

Amongst these methods, we focused in this study on the METRIC model. This model has been applied successfully in many applications for estimation of both evapotranspiration and soil moisture. The METRIC model followed an energy balance approach, where evapotranspiration is estimated as the residual term when net radiation, sensible and soil heat fluxes are known. It uses the principle of surface energy balance to scale sensible and latent heating between wet/cold and dry/hot edges identified within the modeling domain. METRIC (Li et al., 2013) has the particularity of using the hourly reference evapotranspiration in the calculation of evaporative fraction, which makes it the most suitable model for conditions with strong local advection which characterize the semiarid regions in Algeria (Hamimed et al., 2014).

This study aims to evaluate the actual ET by using METRIC remotely sensed-based model. The obtained results are compared with ground observations of wheat and forage using the Bowen ratio Energy Balance (BREB) method. The studied area is located in a semi-arid region of Algeria, where ground data are scarce or difficult to obtain. For this reason, the application of different remotely sensed-based approaches for estimating ET are necessary and the analysis of their sensitivities is important in order to select the most appropriate model.

\section{Study Area and Data}

\subsection{Study area description}

This study area correspond to the Ghriss plain which is a semi-arid agrosystem in the north-west of Algeria, three kilometers away southward from the town of Mascara, between longitudes $0^{\circ} 0{ }^{\prime} 3^{\prime \prime} \mathrm{E}$ and $0^{\circ} 24^{\prime} 42^{\prime \prime} \mathrm{E}$ and latitudes $35^{\circ} 7^{\prime} 54^{\prime \prime} \mathrm{N}$ and $35^{\circ} 27^{\prime} 34^{\prime \prime} \mathrm{N}$. It covers an area of $576 \mathrm{~km}^{2}$ (Fig. 1).

The selected area belongs to the Ghriss plain which is a flat expanse of a surface of about $650 \mathrm{~km}^{2}$ and an average altitude of $470 \mathrm{~m}$, overhung by reliefs of elevated border up to $1100 \mathrm{~m}$ in the South. The lands outcropping are from sedimentary formation with variable texture, consisting mainly of recent and ancient alluvium. Soils are mostly of calcimagnesic type, but sometimes one meets isohumic soils and poorly evolved soils. The northern limit of the plain is distant from the Mediterranean Sea of about $50 \mathrm{~km}$ and its southern boundary is located at a hundred kilometers of the Saharan Atlas. Therefore, it is found submitted to 


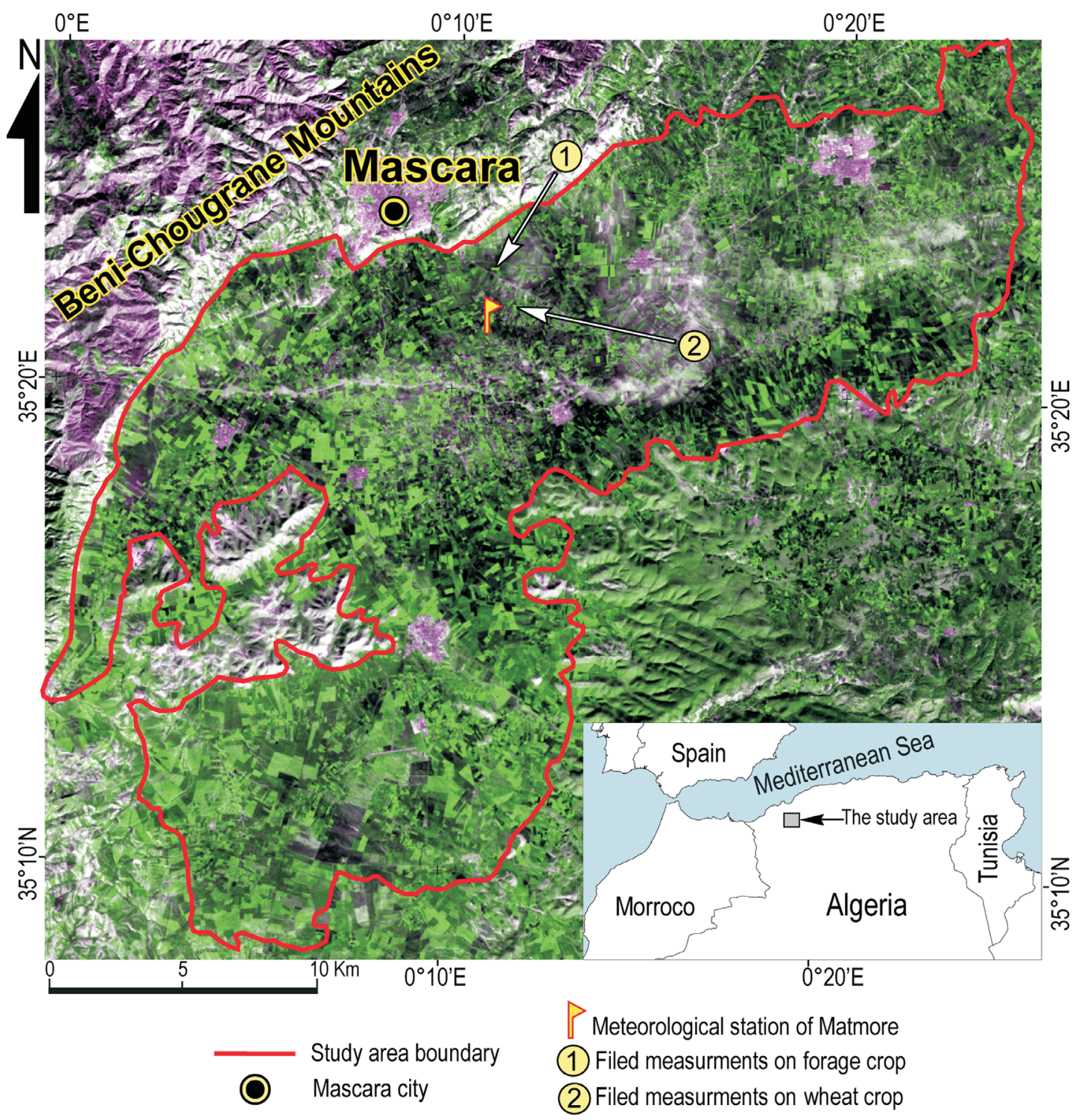

Figure 1 - Location and false color composite 7, 4, 2 of Landsat ETM+ imagery acquired on 5 February 2002 of the study site at Ghriss plain.

Mediterranean and Saharan influences. The latter are clearly predominant due to the screen formed by the Beni-Chougrane Mountains in the North (Bekkoussa et al., 2008).

The study area is characterized by a semi-arid climate and recurrent drought. Two main periods characterize this area, a rainy and dark period during the months of November to April and another dry and hot period during the months of May to September. Winter (from December to February) is usually cold enough. The absolute minimum of the air temperature descends to $-4{ }^{\circ} \mathrm{C}$. Summer (from June to August) is usually hot and dry. The absolute maximum of the air temperature is equal to $+42{ }^{\circ} \mathrm{C}$. Thermal maxima are accentuated by the sirocco, a hot drying wind from the South. Rainfall is concentrated during the cold period. The annual rainfall for the period 1980-2010 oscillates between 200 and $620 \mathrm{~mm}$ (Fig. 2), with an average of about $357 \mathrm{~mm}$ (Bekkoussa et al., 2008). March, April, November and December are the rainiest months of the year, while June, July and August are the hottest months. The evapotranspiration is important during the period of May to September and become lower during the period of October to February.

The study area is characterized by its significant agricultural potential, since more than $90 \%$ of its total area is currently used for agricultural activity. The land use is quite diverse with a predominance of irrigated agriculture, mainly represented by the truck farming, which covers about $70 \%$ of the total of the study area. The forage crops, cereal crops and arboriculture are complementary.

Groundwater which is the main source of irrigation water supply is mobilized by the Ghriss aquifer system. The latter takes the form of a superposition of three layers: the Plio-Quaternary alluvial aquifer, the Pliocene calcareous 


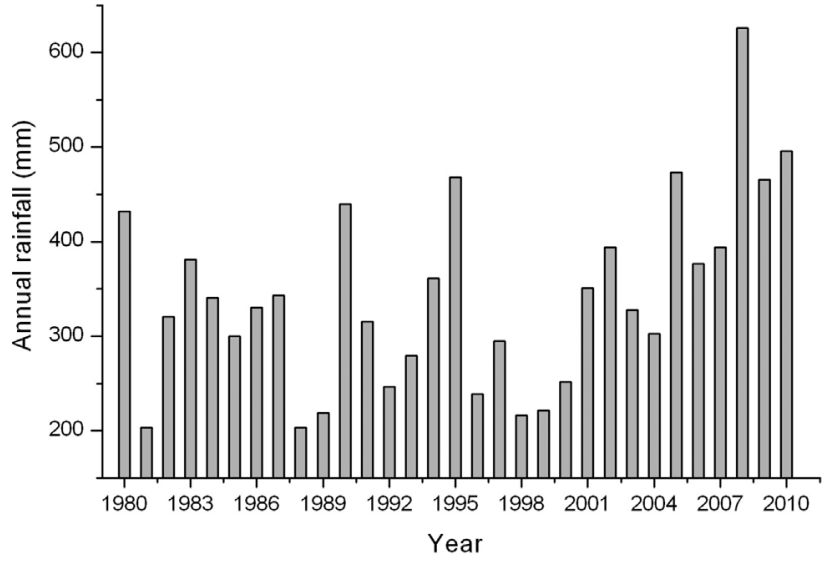

Figure 2 - Annual rainfall recorded at the meteorological station of Matmore during 1980-2010.

sandstone aquifer and the Jurassic calcareous-dolomite aquifer.

\subsection{Data sources}

Remote sensing data used in this study consists of four Landsat-7 ETM+ (Enhanced Thematic Mapper Plus) imagery acquired on December $3^{\text {rd }}, 2001$, February $5^{\text {th }}$, 2002, April $26^{\text {th }}, 2002$ and July $15^{\text {th }}, 2002$.

Optical bands (bands 1, 2, 3, 4, 5 and 7) are used for albedo and vegetation index calculations. Thermal band (band 6) is used for surface temperature. Spatial resolution is $30 \times 30 \mathrm{~m}$ on the optical bands and $60 \times 60 \mathrm{~m}$ on the thermal band. This high spatial resolution is well suited for monitoring evapotranspiration on heterogonous landscapes (Khaldi et al., 2011).

The spectral bands of ETM+ sensor are supplied in digit numbers (encoded into an 8-bit value) which are converted into radiances in the optical (visible, near and medium infrared) and thermal ranges using the linear relationship:

$$
L^{\uparrow} \operatorname{sat}(\lambda)=A \cdot D N+B
$$

where $D N$ is the digit number, $A$ and $B$ are calibration coefficients.

The spectral radiances in the optical range are converted into reflectances after correction for atmospheric effects using MODTRAN 4.0 radiative transfer code (Berk et al., 2016). These reflectances are then used to calculate the albedo $\left(r_{0}\right)$ and vegetation index (NDVI). The albedo $\left(r_{0}\right)$ is defined as a surface reflectance in the shortwave range (0.3-3 $\mu \mathrm{m})$. It is calculated using the formula proposed by Liang et al. (2002):

$$
\begin{aligned}
& r_{0}=0.356 r_{1}+0.13 r_{3}+0.373 r_{4}+0.085 r_{5} \\
& +0.072 r_{7}-0.0018
\end{aligned}
$$

where $r_{1}, r_{3}, r_{4}, r_{5}$ and $r_{7}$ are respectively the reflectances in channels 1, 3, 4, 5 and 7 of ETM+ sensor. The vegetation index (NDVI) is calculated from the reflectances in the red $\left(r_{3}\right)$ and the near infrared $\left(r_{4}\right)$ :

$$
\mathrm{NDVI}=\frac{r_{4}-r_{3}}{r_{4}+r_{3}}
$$

The spectral space-reaching radiance measured by the sensor in the thermal infrared $\left(L_{\text {sat }}^{\uparrow}(\lambda)\right)$ is expressed by the following relationship:

$$
\begin{aligned}
& L_{\text {sat }}^{\uparrow_{1}}(\lambda)=\left[\varepsilon_{0} L_{\lambda}\left(T_{0}\right)+\left(1-\varepsilon_{0}\right) L^{\downarrow} \text { atm }(\lambda)\right] \cdot \tau_{\lambda} \\
& +L_{\text {atm }}^{{ }_{\text {atm }}}(\lambda)
\end{aligned}
$$

where $L_{\lambda}\left(T_{0}\right)$ is the radiance of a blackbody target of kinetic temperature $T_{0}, \tau_{\lambda}$ is the atmospheric transmission, $L_{\text {atm }}^{\downarrow}(\lambda)$ is the down-welling or sky radiance, $L_{\text {atm }}^{\uparrow}(\lambda)$ is the upwelling or atmospheric path radiance and $\varepsilon_{0}$ the surface emissivity which is estimated from the vegetation index (NDVI) by Van de Griend and Owe (1993):

$$
\varepsilon_{0}=1.0094+0.047 \times \ln (\mathrm{NDVI})
$$

The atmospheric parameters $\left(\tau_{\lambda}, L_{\text {atm }}^{\uparrow}(\lambda)\right.$ and $\left.L^{\downarrow}{ }_{\text {atm }}(\lambda)\right)$ are estimated at time of satellite overpass by the web atmospheric correction parameters calculator (Barsi et al., 2003). Spectral radiances $\left(L_{\lambda}\left(T_{0}\right)\right)$ reflected from the Earth surface can be deducted by inversion of Eq. (4). Surface temperatures are finally obtained based on these radiances according to Planck's Law (Chander et al., 2009):

$$
T_{0}=\frac{K_{2}}{\ln \left(\frac{K_{1}}{L_{\lambda}\left(T_{0}\right)}+1\right)}
$$

where $K_{1}=666.09$ and $K_{2}=1282.71$ are the parameters of Landsat $7 \mathrm{ETM}+$.

Remote sensing data are supplemented by ground measurements which were performed on two points located in the experimental site of Agronomy department of Mascara University. The first point was located on forage crop and the second on wheat crop (Fig. 1). These measurements were intended for the daily monitoring of energy fluxes at the soil-plant-atmosphere interface (Hamimed, 2009). They correspond to the radiometric surface temperature, the reflected radiation and the three components of surface energy balance, i.e. soil heat flux $(G)$, sensible heat flux $(H)$ and latent heat flux $(\lambda E)$. Incoming shortwave (solar) and thermal radiations were measured on the meteorological station of Matmore (ONM), located at the center of the study area (Fig. 1) using a pyranometer and a pyrgeometer, respectively. Other incoming shortwave and thermal radiations measurements were performed on a different location and provided very similar results. The meteorological station also provided measurements on the reference variables which are air temperature, relative humidity, wind speed, air pressure, sunshine duration and daily potential evapotranspiration (Table 1). The temperature, humidity and 
Table 1 - Meteorological conditions during the image acquisition of Landsat Thematic Mapper on the selected days.

\begin{tabular}{lccccc}
\hline Parameter & Unit & 03/12/2001 (DOY 337) & 05/02/2002 (DOY 36) & 26/04/2002 (DOY 116) & $15 / 07 / 2002$ (DOY 196) \\
\hline Air temperature & ${ }^{\circ} \mathrm{C}$ & 10.3 & 12.7 & 24 & 25 \\
Relative humidity & $\%$ & 83 & 68 & 28 & 39 \\
Atmospheric pressure & $\mathrm{Mbar}$ & 968.7 & 975 & 965 & 961.4 \\
Incoming shortwave radiation & $\mathrm{W} / \mathrm{m}^{2}$ & 456 & 566 & 888 & 906 \\
Atmospheric radiation & $\mathrm{W} / \mathrm{m}^{2}$ & 294 & 294 & 321 & 362 \\
Atmospheric transmittance & - & 0.694 & 0.716 & 0.777 & 0.769 \\
Wind speed & $\mathrm{m} / \mathrm{s}$ & 0.4 & 2 & 0.5 & 1.2 \\
Daily relative sunshine duration & - & 9.4 & 9.4 & 12.9 & 13.6 \\
Potential evapotranspiration & $\mathrm{mm}$ & 2 & 2.9 & 7.2 & 9.7 \\
\hline
\end{tabular}

wind speed were acquired at $2 \mathrm{~m}$ above the ground with a 10 -second time step and an averaging period of $15 \mathrm{~min}$. A comparison of the data against the data acquired in Ghriss (11 kilometers to the South of Matmore meteorological station) did not show any major failure. On the experimental device, installed on the plots of wheat and forage, the albedo was given by the ratio of the reflected radiation (measured by an Apogee pyranometer (model MP-200) with calibration uncertainty of $\pm 5 \%$ ) and the incoming shortwave radiation. The net radiation $(R n)$ is determined from the radiative balance equation, depending on the albedo, the incoming shortwave and thermal radiations and the surface emission which is deduced from the radiometric surface temperature over the 8-14 $\mu \mathrm{m}$ spectral bands. This radiometric surface temperature is measured by an Apogee infrared radiometer (IRTS-P model). The resolution of this radiometer is $\pm 0.1{ }^{\circ} \mathrm{C}$ and its accuracy is $\pm 0.5^{\circ} \mathrm{C}$. The soil heat flux $(G)$ is measured using Hukseflux conductive flux plates (HFP01SC model) installed at $5 \mathrm{~cm}$ depth in the soil. Sensible and latent heat fluxes were computed by means of the Bowen ratio energy balance (BREB) method from measurements at two levels ( 0.5 and $2.5 \mathrm{~m}$ above the surface) of air temperature using the chromel-alumel thermocouples, and relative humidity using Vaisala capacitive probes (HMP35D model). Generally, the BREB method has 20\% uncertainty (Kustas and Norman, 1999).

All the instruments used in our experiment were calibrated before the experiment by the constructor. The BREB system was closely supervised and general maintenance was provided at least weekly. Maintenance included cleaning the thermocouples and housing units, servicing radiometers by cleaning domes, checking/replacing the desiccant tubes.

\section{Evapotranspiration Estimation with METRIC Model}

METRIC is based on the estimation of latent heat flux $(\lambda E)$ as the residual term of the energy balance equation. This latter describes the energy exchange between the land surface and the atmosphere:

$$
\lambda E=R n-G-H
$$

where $R n$ is the net radiation at the surface $\left(\mathrm{W} / \mathrm{m}^{2}\right), H$ is the sensible heat flux $\left(\mathrm{W} / \mathrm{m}^{2}\right), G$ is the soil heat flux $\left(\mathrm{W} / \mathrm{m}^{2}\right)$ and $\lambda E$ is the latent heat flux (energy consumed by evapotranspiration, $\left.\mathrm{W} / \mathrm{m}^{2}\right)$.

The net radiation $(R n)$ is found from the various components of radiation exchanges:

$$
R n=\left(1-r_{0}\right) \cdot R g+L^{\downarrow}-L^{\uparrow}
$$

where $R g$ is the incoming shortwave radiation, partly reflected depending on the albedo $r_{0}, L^{\downarrow}$ and $L^{\uparrow}$ are the downwelling and the upwelling long wave radiation, respectively.

The soil heat flux $(G)$ is empirically estimated using the expression suggested by Bastiaanssen et al. (1998):

$$
\begin{aligned}
& G=T_{0}\left(0.0032+0.0062 r_{0}\right) \\
& \times\left(1-0.978(\mathrm{NDVI})^{4}\right) \times R n
\end{aligned}
$$

The sensible heat flux $(H)$ is the convective heat loss from the surface to the air created by a near surface temperature gradient. It is expressed as a function of the nearsurface air temperature difference $\left(T_{\text {aero }}-T_{a}\right)$ and the aerodynamic resistance to heat transport $\left(r_{a h}\right)$ as follows:

$$
H=\frac{\rho \cdot C p}{r_{a h}}\left(T_{\text {aero }}-T_{a}\right)
$$

where $\rho$ is air density $\left(\mathrm{kg} / \mathrm{m}^{3}\right), C p$ is air specific heat at constant pressure $(\mathrm{J} / \mathrm{kg} / \mathrm{K}), T_{\text {aero }}$ is the aerodynamic temperature (K), $T_{a}$ is the air temperature $(\mathrm{K})$ and $r_{a h}$ is the aerodynamic resistance to heat transfer which is a function of wind velocity, thermal stability effects of the atmosphere and surface roughness. In satellite remote sensing applications, the radiometric surface temperature $\left(T_{0}\right)$ retrieval is often used instead of the aerodynamic temperature $\left(T_{\text {aero }}\right)$ in Eq. (10), (Kustas et al., 1989).

In METRIC, the sensible heat flux $(H)$ is estimated without needing to know $T_{a}$ or $T_{a e r o}$, instead a temperature difference $(d T)$, a function of $T_{0}$, was used as (Allen et al., 2007): 


$$
H=\frac{\rho \cdot C p}{r_{a h}} d T
$$

where $d T$ is the near-surface temperature difference between two near surface heights $z_{1}=0.1 \mathrm{~m}$ and $z_{2}=2 \mathrm{~m}$ above the canopy layer, and $r_{a h}$ is the aerodynamic resistance to heat transport between these levels $(\mathrm{s} / \mathrm{m}) . d T$ is used in Eq. (11) because of the difficulty in estimating surface temperature $T_{0}$ accurately from satellite due to uncertainty in atmospheric attenuation or contamination and radiometric calibration of the sensor (Allen et al., 2007). In addition, $T_{0}$, as measured by satellite (i.e., radiometric or kinetic temperature) can deviate from the "aerodynamic" temperature that drives the heat transfer process by several degrees (Norman et al., 1995), following (Bastiaanssen et al., 1998) and (Allen et al., 2007).

In METRIC, $r_{a h}$ is calculated between $z_{1}$ and $z_{2}$ using a wind speed extrapolated from some blending height above the ground surface (typically 100 to $200 \mathrm{~m}$ ) and an iterative stability correction scheme for atmospheric heat transfer based on the Monin-Obhukov stability length scale. In this study, a height of $200 \mathrm{~m}$ was used in the calculation of distributed friction velocity $\left(u^{*}\right)$, a term utilized in the estimation of $H$.

In this model, the difference $d T$ between the two near surface heights 0.1 and $2 \mathrm{~m}$ is approximated by a simple linear function:

$$
d T=a \cdot T_{0}+b
$$

The coefficients $a$ and $b$ in Eq. (12) are empirically determined using the properties of pixels in extreme water conditions (hot/cold and dry/wet). These pixels are identified on the image by analyzing the relationship between the vegetation index and the surface temperature according to the triangle method (Hamimed et al., 2014). The dry pixels are indicated at bare soils (NDVI values close to zero) having high surface temperature. However, the wet pixels are indicated at fully vegetation (NDVI $>0.7$ ) having low surface temperature. The thresholds of low and high temperatures are defined as the equilibrium surface temperatures resulting from the energy balance for well-watered dense vegetation and dry bare soil, respectively (Moran et al., 1994).

With the identification of wet and dry pixels, we can determine $H_{w e t}$ and $H_{d r y}$ from the energy balance equation as follows:

$$
\begin{aligned}
& H_{w e t}=(R n-G)_{w e t}-\lambda E_{w e t} \\
& H_{d r y}=(R n-G)_{d r y}-\lambda E_{d r y}
\end{aligned}
$$

A dry pixel is characterized by a zero latent heat flux $\left(\lambda E_{d r y}=0\right)$, which means, the overall available energy $(R n-$ $G)_{d r y}$ is partitioned to sensible heat flux. For a wet pixel, the latent heat flux $\left(\lambda E_{w e t}\right)$ in METRIC is assumed to be equal to the hourly reference evapotranspiration $E T r$, estimated for a hypothetical reference crop, alfalfa, by using Pen-
man-Monteith equation (Allen et al., 1998) multiplied by an empirical coefficient of 1.05 (a wet pixel usually has an evapotranspiration value of 5\% larger than ETr).

With the calculation of $H_{\text {wet }}$ and $H_{d r y}$, Eq. (11) was inverted to compute $d T_{\text {wet }}$ and $d T_{d r y}$. The use of Eq. (11) enables us computing the sensible heat flux in pixel basis and solving the energy balance equation. This step leads mapping the latent heat flux. This should help interpreting accurately the behaviour of a surface with respect to water stress (Bastiaanssen et al., 1998). It is therefore preferable for an easier interpretation to deduce moisture indicators such as the reference evapotranspiration fraction $\left(E F_{r e f}\right)$, the Priestley-Taylor parameter $(\alpha)$ and the surface resistance to evaporation $\left(r_{s}\right)$.

In METRIC, the instantaneous latent heat flux, obtained by Eq. (7), is converted to hourly evapotranspiration $E T_{\text {hor }}$ (in $\mathrm{mm} / \mathrm{h}$ ) according to:

$$
E T_{\text {hor }}=\frac{3600}{\rho \cdot \lambda} \cdot \lambda E
$$

where $\lambda$ is the latent heat of vaporization of water $(\approx 2,45 \times$ $10^{6} \mathrm{~J} / \mathrm{kg}$ at $20^{\circ} \mathrm{C}$ ).

The reference evapotranspiration fraction $\left(E F_{r e f}\right)$ is expressed as the ratio between $E T_{h o r}$ and $E T_{r}$ which is considered similar to its daily counterpart. It is generally used to estimate the daily actual evapotranspiration taking into account the effect of the horizontal advection.

\section{Results and Discussion}

\subsection{Surface temperature}

The surface temperature $\left(T_{0}\right)$ is indirectly related to the latent heat flux $(\lambda E)$ through the energy balance equation (Seguin et al., 1983). It provides important information on surface moisture conditions. The analysis of the correlation between $T_{0}$ and $\lambda E$ for the DOY 36 indicates significantly better agreement between these two variables with $R=-0.92$ (Fig. 3). Moreover, the NDVI and albedo parameters, even if they offer interesting additional information in the interpretation of thermal infrared data (Carlson, 2007; Gillies et al., 1997; Roerink et al., 2000), are less significant in discriminating surface moisture conditions since their determination coefficients with the latent heat flux are respectively 0.0002 and 0.57 .

Surface temperature variations in the study area are shown in Table 2. Higher values correspond to pixels where bare soils (dry pixels) are dominant, while low values are associated with irrigated dense vegetation (wet pixels). Similarly, the average surface temperature on dry pixels is higher than on wet pixels (Table 2).

\subsection{Net radiation}

Higher values of net radiation $(R n)$ are observed over dense vegetation cover (NDVI $>0.7$ ) having optimum wa- 


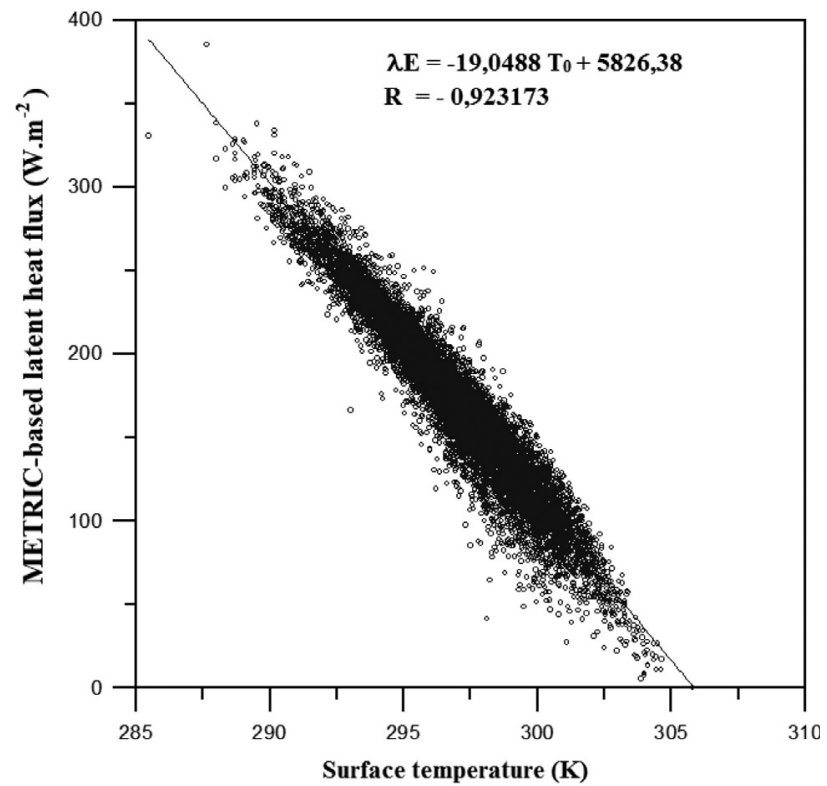

Figure 3 - Relationship between surface temperature and latent heat flux obtained with METRIC model.

ter supply conditions. Bare soils (NDVI $<0.2)$ are characterized by low values of $R n$, with an average of $231 \mathrm{~W} / \mathrm{m}^{2}$, $312 \mathrm{~W} / \mathrm{m}^{2}, 460 \mathrm{~W} / \mathrm{m}^{2}$ and $423 \mathrm{~W} / \mathrm{m}^{2}$ for the DOY 337,36 , 116 and 196 respectively. The comparison between the ground-measured and satellite-estimated net radiation values indicate better agreement, with a root mean square error (RMSE) of $8.71 \mathrm{~W} / \mathrm{m}^{2}$, corresponding to a relative RMSE of $2.7 \%$.

\subsection{Soil heat flux}

For the image acquired on autumn (DOY 337), the average soil heat flux $(G)$ is $21.91 \mathrm{~W} / \mathrm{m}^{2}$. However, the average of $G$ is higher $\left(102.78 \mathrm{~W} / \mathrm{m}^{2}\right)$ in summer (DOY 196), where the temperature is high. Bare soils offer the highest values of $G$, about $22.41 \mathrm{~W} / \mathrm{m}^{2}, 34.87 \mathrm{~W} / \mathrm{m}^{2}, 94.31 \mathrm{~W} / \mathrm{m}^{2}$ and $103.26 \mathrm{~W} / \mathrm{m}^{2}$ for the DOY $337,36,116$ and 196 respectively (Table 3).

For surfaces fully covered by vegetation (NDVI > 0.7), the soil heat flux is of $11.37 \mathrm{~W} / \mathrm{m}^{2}, 18.11$ $\mathrm{W} / \mathrm{m}^{2}, 53.15 \mathrm{~W} / \mathrm{m}^{2}$ and $60.88 \mathrm{~W} / \mathrm{m}^{2}$ for the DOY 337,36 , 116 and 196 respectively.

Comparison between the ground-measured and satellite-estimated soil heat flux values shows that the model leads to an underestimation of the $G$ flux with an RMSE of $13.2 \mathrm{~W} / \mathrm{m}^{2}$, corresponding to a relative RMSE of $27.43 \%$. This result is similar to that obtained on the Alpilles/ReSeDA experimental site in France by Jacob et al. (2002), on the Ksar Chellala plain in Algeria by Hamimed et al. (2014) and on the Low-Middle São Francisco River basin in Brazil by Teixeira et al. (2009). This underestimation can be explained by the uncertainty of the intermediate

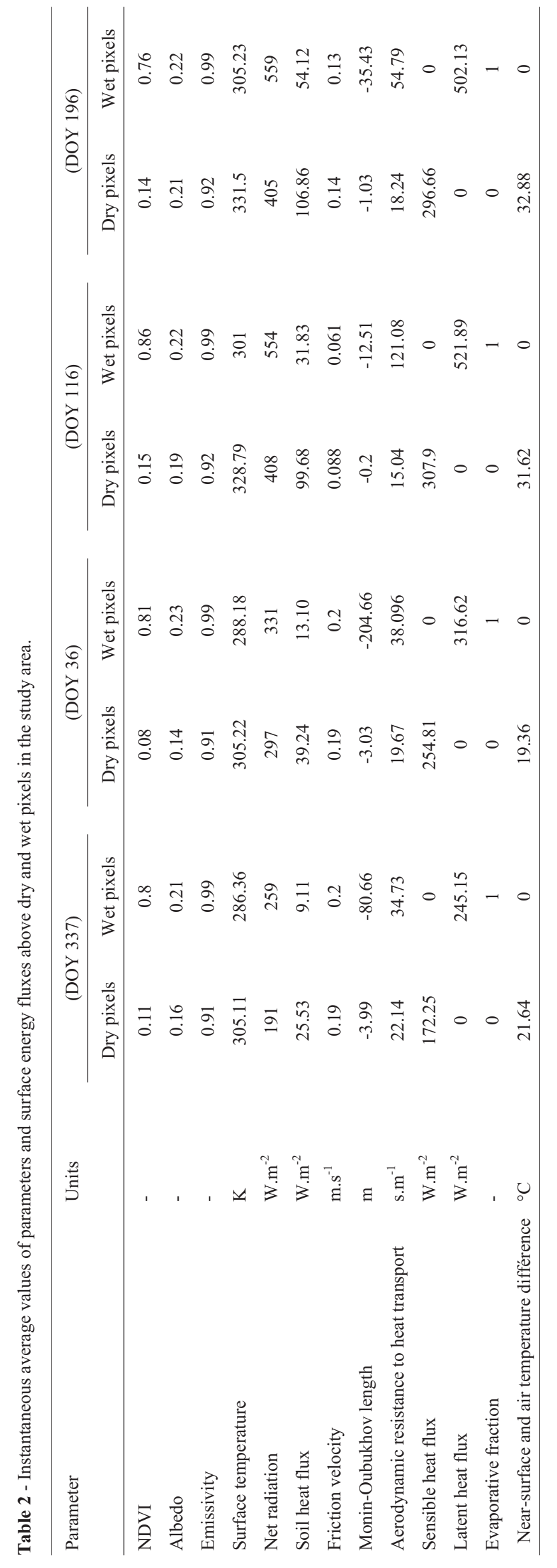


Table 3 - Variation of surface energy fluxes and moisture indicators with land use in the Ghriss plain.

\begin{tabular}{|c|c|c|c|c|c|c|c|c|}
\hline Satellite image date & Land use category & $\mathrm{Rn}\left(\mathrm{W} \cdot \mathrm{m}^{-2}\right)$ & $\mathrm{G}\left(\mathrm{W} \cdot \mathrm{m}^{-2}\right)$ & $\mathrm{H}\left(\mathrm{W} \cdot \mathrm{m}^{-2}\right)$ & $\lambda E\left(\mathrm{~W} \cdot \mathrm{m}^{-2}\right)$ & $E F_{\text {ref }}(-)$ & $\alpha(-)$ & $r_{s}\left(\mathrm{~s} \cdot \mathrm{m}^{-1}\right)$ \\
\hline \multirow[t]{5}{*}{ 03/12/2001 (DOY 337) } & Bare soil & 226 & 22.41 & 71.70 & 131.89 & 0.64 & 0.82 & 193.42 \\
\hline & Sparse vegetation & 250 & 20.37 & 43.85 & 185.78 & 0.80 & 1.10 & 81.36 \\
\hline & Moderate vegetation & 268 & 17.25 & 23.24 & 227.51 & 0.90 & 1.39 & 49.56 \\
\hline & Dense vegetation & 266 & 13.97 & 13.39 & 238.64 & 0.94 & 1.60 & 41.24 \\
\hline & Very dense vegetation & 260 & 11.37 & 9.44 & 239.19 & 0.96 & 1.74 & 31.77 \\
\hline \multirow[t]{5}{*}{ 05/02/2002 (DOY 36) } & Bare soil & 303 & 34.87 & 146.09 & 122.04 & 0.46 & 0.66 & 570.48 \\
\hline & Sparse vegetation & 310 & 32.50 & 111.90 & 165.60 & 0.60 & 0.84 & 252.24 \\
\hline & Moderate vegetation & 321 & 28.63 & 76.92 & 215.45 & 0.74 & 1.14 & 141.68 \\
\hline & Dense vegetation & 326 & 26.34 & 41.37 & 258.29 & 0.85 & 1.44 & 73.13 \\
\hline & Very dense vegetation & 326 & 18.11 & 26.34 & 281.55 & 0.91 & 1.60 & 47.29 \\
\hline \multirow[t]{5}{*}{ 26/04/2002 (DOY 116) } & Bare soil & 421 & 94.31 & 189.33 & 137.36 & 0.41 & 0.54 & 792.50 \\
\hline & Sparse vegetation & 459 & 92.15 & 131.52 & 235.33 & 0.63 & 0.67 & 234.57 \\
\hline & Moderate vegetation & 515 & 81.46 & 52.94 & 380.60 & 0.87 & 0.99 & 57.22 \\
\hline & Dense vegetation & 537 & 67.34 & 26.24 & 443.42 & 0.94 & 1.17 & 48.24 \\
\hline & Very dense vegetation & 539 & 53.15 & 15.03 & 470.82 & 0.96 & 1.29 & 57.77 \\
\hline \multirow[t]{5}{*}{ 15/07/2002 (DOY 196) } & Bare soil & 415 & 103.26 & 202.16 & 109.58 & 0.34 & 0.42 & 1136.84 \\
\hline & Sparse vegetation & 464 & 101.46 & 137.31 & 225.23 & 0.61 & 0.67 & 298.94 \\
\hline & Moderate vegetation & 527 & 90.60 & 61.65 & 374.75 & 0.85 & 1.04 & 63.13 \\
\hline & Dense vegetation & 542 & 75.29 & 32.27 & 434.44 & 0.92 & 1.23 & 35.16 \\
\hline & Very dense vegetation & 548 & 60.88 & 14.38 & 472.74 & 0.96 & 1.31 & 27.77 \\
\hline
\end{tabular}

variables used in the model (such as albedo, NDVI and surface temperature). Despite this imprecision, $G$ flux has a small impact on the available energy $(R n-G)$; because it is lower than the other energy fluxes (Jacob et al., 2002).

\subsection{Sensible heat flux}

The approach used in our study is based on the Monin-Oubukhov similarity theory in the atmospheric boundary layer. In fact, the surface boundary layer modeling allows mapping the sensible heat flux which is obtained by estimating two key parameters of the energy balance regulation, depending on the surface type and its thermodynamic properties which are the aerodynamic resistance to heat transfer $\left(r_{a h}\right)$ and the surface-air temperatures difference.

In the sensible heat flux $(H)$ estimation, wet pixels are identified on dense vegetation cover (NDVI $>0.7$ ), with an average temperature values of $286.36 \mathrm{~K}, 288.18 \mathrm{~K}, 301 \mathrm{~K}$ and $305.23 \mathrm{~K}$ for the DOY $337,36,116,196$, respectively (Table 2).

We note also on Table 2 that for dry pixels (bare soil and urban) the aerodynamic resistance to heat transfer $\left(r_{a h}\right)$ is low $(22.14 \mathrm{~s} / \mathrm{m}, 19.67 \mathrm{~s} / \mathrm{m}, 15.04 \mathrm{~s} / \mathrm{m}$ and $18.24 \mathrm{~s} / \mathrm{m}$ for the DOY $337,36,116,196$, respectively), causing the release of sensible heat to the atmosphere. This is justified by high differences between surface and air temperatures. However, for wet pixels (freshly irrigated plots) $r_{a h}$ values are high $(34.73 \mathrm{~s} / \mathrm{m}, 38.09 \mathrm{~s} / \mathrm{m}, 121.08 \mathrm{~s} / \mathrm{m}$ and $54.79 \mathrm{~s} / \mathrm{m}$ for the DOY $337,36,116,196$, respectively) because the net available energy $(R n-G)$ is mainly consumed by evapotranspiration (Hamimed et al., 2014). This differentiation of the sensible heat flux for dry and wet pixels is caused by the surface water status and its influence on the energy partition between the latent and sensible heat. Specifically, wet surfaces are individualized by low $H$ values while high $H$ values are assigned to dry areas (Table 2 ).

\subsection{Latent heat flux}

The results presented in Table 3 summarize the energy fluxes and moisture indicators (reference evaporeanspiration fraction $E F_{\text {ref, }}$, Priestley-Taylor parameter $\alpha$ and surface resistance to evaporation $r_{s}$ ) obtained from the METRIC model for different land use units. It shows that high values of evapotranspiration $(\lambda E)$ are observed on the irrigated areas with dense vegetation, while low values are on the bare soils, corresponding to high values of albedo. This allows emphasizing that the spatial distribution of METRIC-derived evapotranspiration is correlated to the water regimes of the different land use units. However, the estimated latent heat flux should be considered with caution and have only a relative value, because there is no method of validation over wide scales of time and space (Khaldi et al., 2011).

A method commonly used for validating the obtained results is to compare latent heat flux values obtained with METRIC model from the image with those estimated on 
the ground using the BREB technique (Hamimed, 2009). Kustas and Norman (1999) indicated that this technique have $\sim 20 \%$ uncertainty, hence, when discrepancies between model predicted and ground observed heat fluxes are less than $\sim 20 \%$, the performance of model is deemed acceptable. The result of comparison between remote sensing-estimated and ground-measured latent heat flux is shown in Fig. 4. It shows a significant discrepancy between remote sensing and ground estimates of latent heat flux, with a RMSE about $36.1 \mathrm{~W} \cdot \mathrm{m}^{-2}$, which correspond to $15.80 \%$ in relative value and a determination coefficients $\left(R^{2}\right)$ of 0.87 . This result is closely similar to that obtained on the Low-Middle São Francisco River basin in Brazil (RMSE $=33.8 \mathrm{~W} / \mathrm{m}^{2}$ ) by Teixeira et al. (2009). Finally, the results obtained on $\lambda E$ flux show excellent agreements to justify that METRIC applied to the Ghriss site is promising for remotely sensed evapotranspiration monitoring.

Figure 5 shows the spatial distributions of latent heat fluxes $(\lambda E)$ derived from METRIC model. The METRIC calculates $H$ using a single-source temperature gradient technique for heat transport, accounting for stability effects based on the Monin-Obukhov theory, and $\lambda E$ is computed as a residual term of the energy balance equation. Based on the identified spatial patterns for $H$ and $\lambda E$, the METRIC computational scheme seems to be more physically comprehensive considering the stability for the aerodynamic resistance of heat transport (Choi et al., 2011).

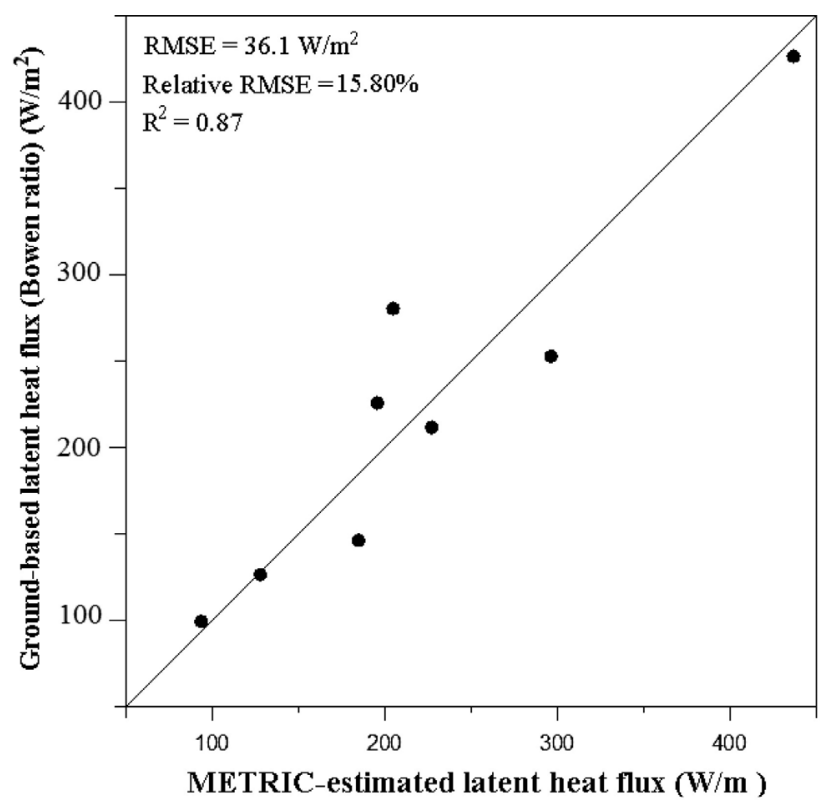

Figure 4 - Comparison of ground-based and satellite-derived METRIC estimates of latent heat fluxes.
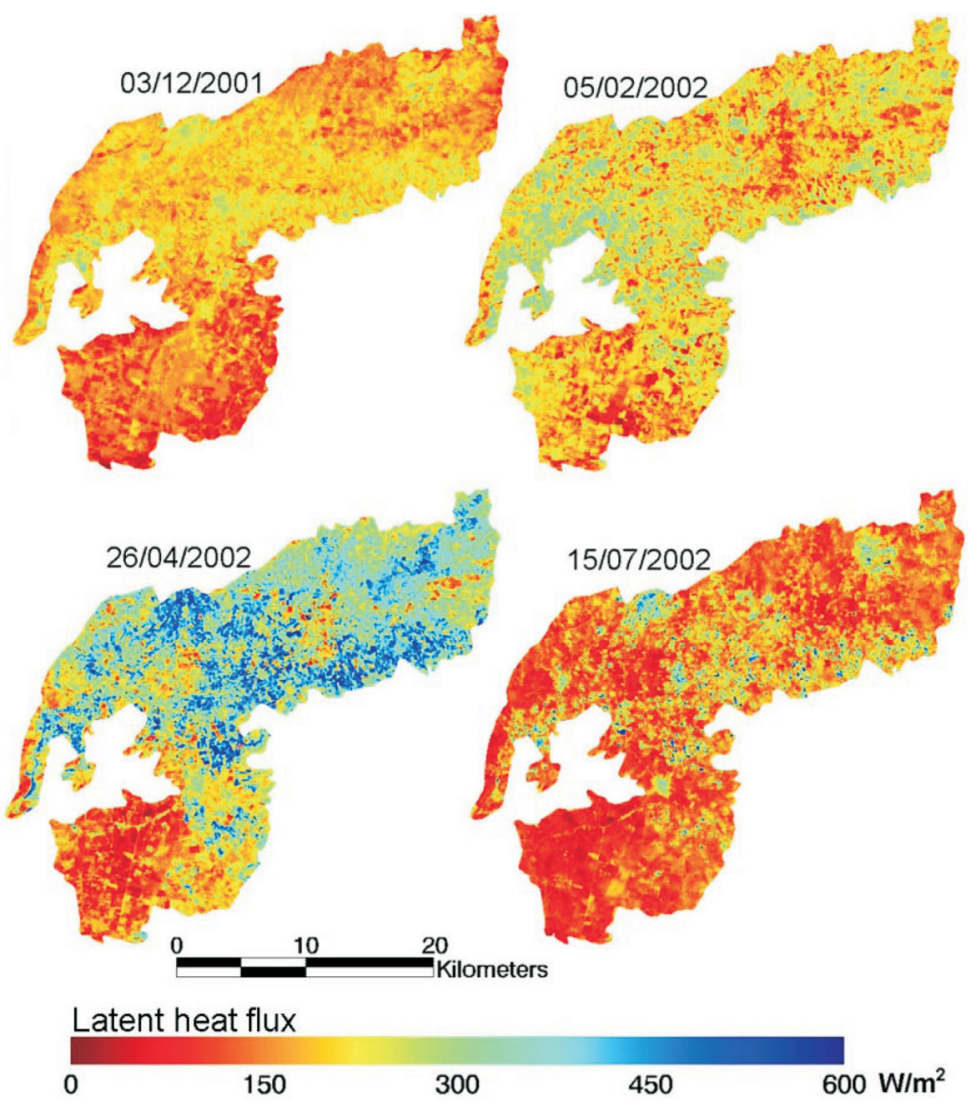

Figure 5 - Spatial distributions of latent heat flux estimated with METRIC on December $3^{\text {rd }}, 2001$, February $5^{\text {th }}, 2002$, April $26^{\text {th }}, 2002$ and July $15^{\text {th }}$, 2002. 

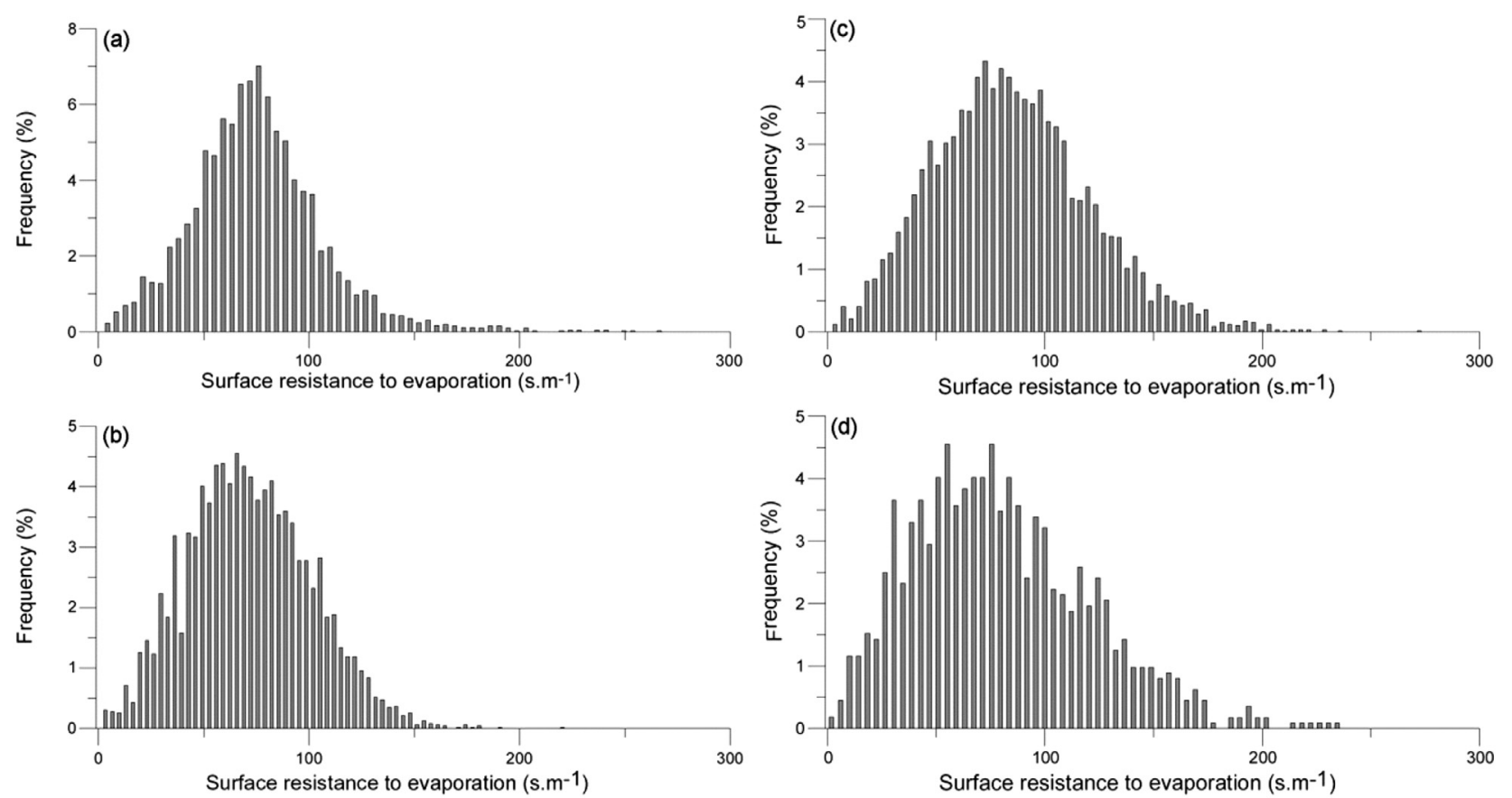

Figure 6 - Frequency distributions of the surface resistance to evaporation estimated with METRIC on December $3^{\text {rd }}, 2001$ (a), February $5^{\text {th }}, 2002(\mathrm{~b})$, April $26^{\text {th }}, 2002$ (c) and July $15^{\text {th }}, 2002$ (d) for pixels with NDVI values more than 0.6 .

The result leads to the conclusion that METRIC model can be considered as operational approach for monitoring evapotranspiration over agricultural areas having limited amount of ground information.

The analysis of frequency distribution of surface resistance to evaporation (Fig. 6) is considered another way to validate our results. Bastiaanssen et al. (1996) showed that for most crops covering fully soil, values of this resistance vary between 10 and $300 \mathrm{~s} / \mathrm{m}$ with generally peaking in the class of 30 to $80 \mathrm{~s} / \mathrm{m}$. There is a general consensus that the surface resistance for crops which cover the soil entirely lies in approximately the same range (Bougeault et al., 1991). The results shown in Fig. 6 are approximately consistent with this indication.

\section{Conclusion}

Different models have been developed to estimate evapotranspiration from remote sensing data. The METRIC energy balance model was applied using Landsat ETM+ data in the Ghriss plain in Mascara (western Algeria), a semiarid region with heterogeneous surface conditions, to estimate actual evapotranspiration. The model outputs were compared with field observations using the Bowen ratio energy balance method.

METRIC is a residual model based on the energy balance equation resolution by calculating the net radiation first, then the soil and the sensible heat fluxes, and then the latent heat flux (the actual evapotranspiration) is calculated as the residual term of the energy balance equation.
A significant discrepancy between remote sensing and ground estimates of latent heat flux is shown, with an RMSE values of $36.1 \mathrm{~W} / \mathrm{m}^{2}$, i.e. $15.80 \%$ in relative terms and a determination coefficients $\left(R^{2}\right)$ of 0.87 , which is attributed to errors in the estimation of the net radiation, the soil heat flux and the sensible heat flux, which correspond to a RMSE between estimates and measurements of $8.71 \mathrm{~W} / \mathrm{m}^{2}(2.7 \%), 13.2 \mathrm{~W} / \mathrm{m}^{2}(27.43 \%)$, and $36,1 \mathrm{~W} / \mathrm{m}^{2}$ $(15.80 \%)$.

The results presented above confirm the possibilities offered by the Landsat ETM + satellite data to solve the energy balance equation, and to estimate the evapotranspiration. They lead to the conclusion that the METRIC model provide comparable outputs and can be considered as operational approach for evapotranspiration spatialization over agricultural areas where ground information is scarce or difficult to collect.

\section{Acknowledgments}

This work was supported by the PHC-MAGHREB Program, (No. 14MAG927). The authors acknowledge Dr. A.H. De C. Teixeira (Embrapa Satellite Monitoring, Campinas, São Paulo, Brazil) for the translation support and the national meteorology office (ONM) in Mascara (Algeria) for supplying climatic data.

\section{References}

ALLEN, R.G.; PEREIRA, L.A.; RAES, D.; SMITH, M. Crop evapotranspiration guidelines for computing crop water re- 
quirements. FAO Irrigation and Drainage Paper 56, v. 300, n. 9, 1998. D05109.

ALLEN, R.G.; TASUMI, M.; TREZZA, R. Satellite-based energy balance for mapping evapotranspiration with internalized calibration (METRIC)-Model. Journal of Irrigation and Drainage Engineering, v. 133, n. 4, p. 380-394, 2007.

BARSI, J.A.; BARKER, J.L.; SCHOTT, J.R. An Atmospheric Correction Parameter Calculator for a Single Thermal Band Earth-Sensing Instrument. J. Proc. IEEE. Int. v. 5, p. 3014-3016, 2003.

BASTIAANSSEN, W.G.M.; VANDERWALL, T., VISSER, T.N.M. Diagnosis of regional evaporation by remote sensing to support irrigation performance assessment. Irrigation and Drainage Systems, v. 10, n. 1, p. 1-23, 1996.

BASTIAANSSEN, W.G.M.; MENENTI, M.; FEDDES, R.A.; HOLTSLAG, A.A.M. A remote sensing surface energy balance algorithm for land (SEBAL): 1. Formulation. Journal of Hydrology, v. 212, p. 198-212, 1998.

BEKKOUSSA, B.; MEDDI, M.; JOURDE, H. Forçage climatique et anthropique sur la ressource en eau souterraine d'une région semi-aride : cas de la plaine de Ghriss, nordouest algérien. Revue Sécheresse, v. 19, n. 3, p. 173-184, 2008.

BERK, A.; CONFORTI, P.; HAWES, F.; PERKINS, T.; GUIANG, C.; ACHARYA, P. Next Generation MODTRAN for Improved Atmospheric Correction of Spectral Imagery. Spectral Sciences, Inc. Burlington United States, 2016.

BOUGEAULT, P.; NOILHAN, J.; LACARRERE, P.; MASCART, P. An experiment with an advanced surface parameterization in a mesobeta-scale model. Part I: Implementation. Monthly. Weather. Review. V. 119, n. 10, p. 23582373, 1991.

BOULET, G.; MOUGENOT, B.; LHOMME, J.P.; FANISE, P.; LILI-CHABAANE, Z.; OLIOSO, A.; BAHIR, M.; RIVALLAND, V.; JARLAN, L.; MERLIN, O.; COUDERT, B.; ER-RAKI, S.; LAGOUARDE, J.P. The SPARSE model for the prediction of water stress and evapotranspiration components from thermal infra-red data and its evaluation over irrigated and rainfed wheat. J. Hydrol. Earth. Syst. Sci. Discuss. v. 19, p. 4653-4672, 2015.

CARLSON, T.N. An Overview of the "Triangle Method" for Estimating Surface Evapotranspiration and Soil Moisture from Satellite Imagery. Sensors, v. 7, n. 8, p. 1612-1629, 2007.

CHANDER, G.; MARKHAM, B.L.; HELDER, D.L. Summary of current radiometric calibration coefficients for Landsat MSS, TM, ETM+, and EO-1 ALI sensors. J. Remote. Sens. Environ, v. 113, n. 5, p. 893-903, 2009.

CHOI, M.; KIM, T.W.; PARK, M.; KIM, S.J. Evapotranspiration estimation using the Landsat-5 Thematic Mapper image over the Gyungan watershed in Korea. International Journal of Remote Sensing, v. 32, n. 15, p. 4327-4341, 2011.

FRENCH, A.N.; HUNSAKER, D.J.; THORP, K.R. Remote sensing of evapotranspiration over cotton using the TSEB and METRIC energy balance models. Remote Sensing of Environment, v. 158, p. 281-294, 2015.

GALlEGUILLOS, M.; JACOB, F.; PRÉVOT, L.; FAUNDEZ, C.; BSAIBES, A. Estimation of actual evapotranspiration over a rainfed vineyard using a 1-D water transfer model: A case study within a Mediterranean watershed. Agricultural Water Management, v. 184, p. 67-76, 2017.
GILLIES, R.R.; CARLSON, T.N.; CUI, J.; KUSTAS, W.P.; HUMES, K.S. Averification of the 'triangle' method for obtaining surface soil water content and energy fluxes from remote measurement of the Normalized Difference Vegetation Index (NDVI) and surface radiant temperature. International Journal of Remote Sensing, v. 18, n. 15, p. 3145-3166, 1997.

HAMIMED, A. Suivi de l'état hydrique d'une région semi-aride dans l'ouest algérien à partir des images de télédétection haute et faible résolution. 2009, p. 179. Ph.D. Thesis Tlemcen University, Algeria, 2009.

HAMIMED, A.; NEHAL, L.; KHALDI, A.; AZZAZ, H. Contribution à la spatialisation de l'évapotranspiration d'un agrosystème semi-aride en Algérie par utilisation de la télédétection et du modèle METRIC. Géographie Physique et Environnement, v. 8, p. 197-213, 2014.

HARTANTO, I.M.; VAN DER KWAST, J.; ALEXANDRIDIS, T.K.; ALMEIDA, W.; SONG, Y.; VAN ANDEL, S.J.; SOLOMATINE, D.P. Data assimilation of satellite-based actual evapotranspiration in a distributed hydrological model of a controlled water system. International Journal of Applied Earth Observation and Geoinformation, v. 57, p. 123-135, 2017.

JACOB, F.; OLIOSO, A.; GU, X.F.; SU, Z.; SEGUIN, B. Mapping surface fluxes using airbornevisible, near infrared, thermal infrared remote sensing data and a spatialized surface energybalance model. Agronomie, v. 22, n. 6, p. 669-680, 2002.

JATO-ESPINO, D.; CHARLESWORTH, S.M.; PERALESMOMPARLER, S.; ANDRÉS-DOMÉNECH, I. Prediction of Evapotranspiration in a Mediterranean Region Using Basic Meteorological Variables. Journal of Hydrologic Engineering, p. 04016064, 2016.

KHALDI, A.; HAMIMED, A.; MEDERBAL, K.; SEDDINI, A. Obtaining evapotranspiration and surface energy fluxes with remotely sensed data to improve agricultural water management. African Journal of Food. Agriculture. Nutrition and Development, v. 11, n. 1, 2011.

KUSTAS, W.; CHOUDHURY, B.; REGINATO, M.M.R.; JACKSON, R.; GAY, L.; WEAVER, H. Determination of sensible heat flux over sparse canopy using thermal infrared data. Agricultural and Forest Meteorology, v. 44, p. 197216, 1989.

KUSTAS, W.P; NORMAN, J.M. Evaluation of soil and vegetation heat flux predictions using a simple two-source model with radiometric temperatures for partial canopy cover. Agricultural and Forest Meteorology, v. 94, n. 1, p. 13-29, 1999.

LI, Z.; LIU, X.; MA, T.; KEJIA, D.; ZHOU, Q.; YAO, B.; NIU, T. Retrieval of the surface evapotranspiration patterns in the alpine grassland-wetland ecosystem applying SEBAL model in the source region of the Yellow River, China. Ecological Modelling, v. 270, p. 64-75, 2013.

LIANG, S.; SHUEY, C.; RUSS, A.; FANG, H.; CHEN, M.; WALTHALL, C.; DAUGHTRY, C. Narrowband to Broadband Conversions of Land Surface Albedo: II. Validation. J. Remote. Sens. Environ. v. 84, n. 1, p. 25-41, 2002.

LIOU, Y.A.; KAR, S.K. Evapotranspiration estimation with remote sensing and various surface energy balance algorithms-A review. Energies, v. 7, n. 5, p. 2821-2849, 2014. 
MORAN, M.S.; CLARKE, T.R.; INOUE, Y.; VIDAL, A. Estimating crop water deficit using the relation between surface-air temperature and spectral vegetation index. J. Remote. Sens. Environ, v. 49, n. 3, p. 246-263, 1994.

MUZYLEV, E.L.; USPENSKII, A.B.; STARTSEVA, Z.P.; VOLKOVA, E.V.; KUKHARSKI, I. A.V. Modelling water and heat balance components for the river basin using remote sensing data on underlying surface characteristics. Russian Meteorology and Hydrology, v. 35, n. 3, p. 225235, 2010.

NORMAN, J.M.; DIVAKARLA, M.; GOEL, N.S. Algorithms for extracting information from remote thermal-IR Observations of the earth's surface. J. Remote. Sens. Environ, v. 51, p. 157-168, 1995.

OLIOSO, A.; CHAUKI, H.; COURAULT, D.; WIGNERON, J.P. Estimation of evapotranspiration and photosynthesis by assimilation of remote sensing data into SVAT models. J. Remote. Sens. Environ, v. 68, n. 3, p. 341-356, 1999.

ROERINK, G.J.; SU, Z.; MENENTI, M. S-SEBI: a simple remote sensing algorithm to estimate the surface energy balance. J. Phys. Chem. Earth, v. 25, p. 147-157, 2000.

SEGUIN, B.; ITIER, B. Using midday surface temperature to estimate daily evaporation from satellite thermal IR data. Int. J. Remote. Sens, v. 4, n. 2, p. 371-383, 1983.

STISEN, S.; SANDHOLT, I.; NORGAARD, A.; FENSHOLT, R.; JENSEN, K.H. Combining the triangle method with thermal inertia to estimate regional evapotranspirationapplied to MSG-SEVIRI data in the Senegal River basin. J. Remote. Sens. Environ, v. 112, n. 3, p. 1242-1255, 2008.

SU, Z. The Surface Energy Balance System (SEBS) for estimation of turbulent heat fluxes atscales ranging from a point to a continent. J. Hydrol. Earth. Syst. Sci, v. 6, n. 1, p. 85-99, 2002.
SUN, D.; KAFATOS, M. Note on the NDVI-LST relationship and the use of temperature-related drought indices over North America. Geophysical Research Letters, v. 34, n. 24, 2007.

TEIXEIRA, A.D.C.; BASTIAANSSEN, W.G.M.; AHMAD, M.; BOS, M.G. Reviewing SEBAL input parameters for assessing evapotranspiration and water productivity for the LowMiddle Sao Francisco River basin, Brazil: Part A: Calibration and validation. Agricultural and Forest Meteorology, v. 149, n. 3, p. 462-476, 2009.

TREZZA, R. Evapotranspiration from a remote sensing model for water management in an irrigtion system in Venezuela. Interciencia. Caracas, v. 31, n. 6, p. 417-423, 2006.

TREZZA, R.; ALLEN, R.G.; TASUMI, M. Estimation of actual evapotranspiration along the Middle Rio Grande of New Mexico using MODIS and landsat imagery with the METRIC model. Int. J. Remote. Sens, v. 5, n. 10, p. 5397 5423, 2013.

VAN DE GRIEND, A.A.; OWE, M. On the relationship between thermal emissivity and the normalized difference vegetation index for natural surfaces. Int. J. Remote. Sens, v. 14, p. 1119-1131, 1993.

XIN, X; LIU, Q. The Two-layer Surface Energy Balance Parameterization Scheme (TSEBPS) for estimation of land surface heat fluxes. J. Hydrol. Earth. Syst. Sci, v. 14, p. 491504, 2010. doi: 10.5194/hess-14-491-2010.

ZHANG, K.; KIMBALL, J.S.; RUNNING, S.W. A review of remote sensing based actual evapotranspiration estimation. Wiley Interdisciplinary Reviews: Water, v. 3, n. 6, p. 834-853, 2016.

This is an Open Access article distributed under the terms of the Creative Commons Attribution Non-Commercial License which permits unrestricted non-commercial use, distribution, and reproduction in any medium provided the original work is properly cited. 